Jurnal Psikologi Malahayati, Volume 3, No.1, Maret 2021: 39-46

\title{
FAKTOR-FAKTOR PEMICU STRES PADA SISWA SMA SELAMA PEMBELAJARAN DARING
}

\author{
Deswita Anggrini \\ Program Studi Psikologi Fakultas IImu Pendidikan Universitas Negeri Padang, email : \\ deswita.anggrini@gmail.com.
}

\section{ABSTRACT : STRESS TRIGGERING FACTORS IN STUDENTS DURING ONLINE LEARNING}

This study aimed to explore the problems experienced by students during online learning that cause stress. This research is focused on senior high school students, where they have a bigger responsibility, that is, they will soon enter university level. This research is a qualitative research involving 50 male $(n=$ $7)$ and female $(n=43)$ student informants who attend high school $(n=40)$, and MA $(n=10)$ in Tanah Datar District. Informants are asked to fill in open and closed questions related to research topics through an online form (google form). The results of the study found that the triggers for academic stress in Tanah Datar was difficulty in doing assignments, not understanding learning materials, and unstable internet networks and insufficient internet quotas. The efforts made to overcome the existing obstacles are asking for help / asking teachers and friends, and trying to find solutions to any problems that arise.

\section{Keyword: Stress, Online Learning, High School Students.}

Penelitian ini bertujuan untuk menggali permasalahan-permasalahan yang dialami oleh siswa selama pembelajaran daring hingga menimbulkan stress. Penelitian ini difokuskan pada siswa-siswi Sekolah Menengah Atas, dimana mereka memiliki tanggungjawab yang lebih besar yaitu mereka akan segera memasuki jenjang perguruan tinggi. Penelitian ini merupakan penelitian kualitatif dengan melibatkan 50 informan siswa Laki-Laki $(n=7)$ dan perempuan $(n=43)$ yang bersekolah di SMA $(n=40)$, dan MA $(n=10)$ di Kabupaten Tanah Datar. Informan diminta untuk mengisi pertanyaan terbuka dan tertutup terkait topik penelitian melalui formulir daring (google form). Hasil penelitian menemukan faktor pemicu stres akademik di Kabupaten Tanah Datar ialah karena kesulitan dalam mengerjakan tugas, tidak memahami materi pembelajaran, jaringan internet yang tidak stabil dan kuota internet yang tidak mencukupi. Adapun upaya yang dilakukan untuk mengatasi kendala yang ada ialah meminta bantuan / bertanya kepada guru dan teman, serta berusaha mencari solusi dari setiap masalah yang muncul.

\section{Kata kunci: Stres, Belajar Daring, Siswa SMA.}

\section{PENDAHULUAN}

Wabah Covid-19 melanda Indonesia semenjak bulan maret 2020. Covid-19 ialah sekelompok virus yang bisa menyebabkan penyakit pada hewan atau manusia. Pada manusia, virus corona menyebabkan infeksi saluran pernapasan yang umumnya ringan, seperti pilek, demam tinggi, batuk berdahak, sesak napas, nyeri tenggorokan, pilekpneumonia (infeksi pada paru-paru) dan mudah merasa lelah. Wabah Covid-19 ini telah menimbulkan berbagai dampak negatif bagi berbagai kalangan masyarakat, baik di kota maupun pedesaan, salah satunya di dalam bidang pendidikan. Dimana Menteri Pendidikan dan Kebudayaan (Mendikbud) Indonesia membuat kebijakan terkait belajar di rumah yang bertujuan untuk mengurangi terjadinya interaksi 
Jurnal Psikologi Malahayati, Volume 3, No.1, Maret 2021: 39-46

\section{FAKTOR-FAKTOR PEMICU STRES PADA SISWA SMA SELAMA PEMBELAJARAN DARING}

fisik sehingga akan memperkecil kemungkinan penularan virus Covid-19 dan bahkan Mendikbud membatalkan ujian nasional 2020. Mendikbud berharap dengan diterapkannya pembelajaran daring atau jarak jauh ini siswa juga mendapatkan pengalaman baru dalam proses belajar (Asmara, 2020; Fajar, 2020).

Belajar dari rumah (daring) adalah suatu metode pelaksanaan pembelajaran jarak jauh yang dilaksanakan dari rumah masingmasing untuk memenuhi hak peserta didik agar tetap mendapatkan layanan pendidikan selama wabah covid-19 ini. Reva (2014) menjelaskan bahwa pembelajaran jarak jauh ialah pembelajaran yang memanfaatkan teknologi untuk menyampaikan pendidikan kepada peserta didik yang tidak terikat ruang, waktu dan personal, serta menyesuaikan dengan kapabilitas masing-masing peserta didik tanpa adanya unsur pemaksanaan dengan standar tertentu.

Pembelajaran secara daring memiliki beberapa kelebihan dan beberapa kendala dalam penerapannya. Kelebihannya ialah membuat kegiatan pembelajaran menjadi mudah dilakukan dalam berbagai waktu dan tempat, memungkinkan siswa untuk mendapatkan informasi yang lebih banyak (Shukla, Dosaya, Nirban, \& Vavilala, 2020; Hastini, Fahmi, \& Lukito, 2020). Sedangkan kendalanya ialah di beberapa daerah tertentu jaringannya tidak memadai, memunculkan pengeluaran baru untuk kuota internet sehingga hal ini bisa menjadi masalah bagi yang mengalami kesulitan finansial dan model belajar dengan menggunakan online menimbulkan kebosanan dan kejenuhan karena kurang efektifnya interaksi secara online bahkan bisa menyebabkan stress (Hastini, Fahmi, \& Lukito, 2020 \& Morgan, 2020). Kesuksesan dari penerapan pembelajaran daring juga tergantung dari kesiapan sekolah penyelenggara serta guru pengajar (Rusdiana \& Nugroho, 2020). Tidak semua guru mampu menyampaikan keseluruhan materi dengan optimal melalui sistem pembelajaran daring (Morgan, 2020).

Robbins (2001) menyebutkan bahwa stres ialah ketika berada dalam kondisi yang menekan psikis seseorang untuk mencapai suatu tujuan, namun terdapat batasan atau penghalang. Stres akademik ialah stres yang disebabkan karena terbebani dengan adanya tekanan-tekanan untuk menunjukkan prestasi dan keunggulan dalam persaingan akademik yang semakin meningkat. Stres akademik yang dialami siswa merupakan hasil persepsi yang subjektif terhadap adanya ketidaksesuaian antara tuntutan lingkungan dengan sumber daya aktual yang dimiliki siswa (Agista, 2011).

$$
\begin{aligned}
& \text { Menurut Desmita (2010), terdapat } \\
& \text { empat macam stress akademik yang } \\
& \text { disebabkan oleh beberapa aspek sebagai } \\
& \text { berikut: } \\
& \text { a. Physical Demands (Tuntutan Fisik), ialah } \\
& \text { tuntutan yang bersumber dari lingkungan } \\
& \text { fisik sekolah diantaranya indikatornya }
\end{aligned}
$$

Deswita Anggrini, Program Studi Psikologi Fakultas Ilmu Pendidikan Universitas Negeri Padang. Email: deswita,anggrini@gmail.com 
Jurnal Psikologi Malahayati, Volume 3, No.1, Maret 2021: 39-46

\section{FAKTOR-FAKTOR PEMICU STRES PADA SISWA SMA SELAMA PEMBELAJARAN DARING}

seperti; keadaan iklim ruang kelas, temperatur yang tinggi (temperature extremes), pencahayaan dan penerangan (ligthing and illumination), sarana dan prasarana penunjang pembelajaran, kebersihan dan kesehatan sekolah keamanan sekolah dan sebagainya.

b. Task Demands (Tuntutan Tugas), ialah tuntutan dari berbagai tugas-tugas pelajaran (academic work) yang menimbulkan perasaan tertekan pada siswa. Indikatornya ialah adalah tugastugas yang dikerjakan di sekolah (classwork), dan tugas-tugas yang di kerjakan di rumah (homework), tuntutan kurikulum, menghadapi ujian atau ulangan, kedisiplinan di sekolah, dan mengikuti berbagai kegiatan ekstrakurikuler.

c. Role Demands (Tuntutan Peran) merupakan sekumpulan kewajiban yang harus dipenuhi oleh siswa terkait dengan pemenuhan fungsi pendidikan di sekolah. Indikatornya ialah harapan memiliki nilai yang memuaskan, mempertahankan prestasi sekolah, memiliki sikap yang baik, memiliki motivasi belajar yang tinggi, memiliki ketrampilan yang lebih.

d. Interpersonal Demands (Tuntutan Interpersonal), ialah tuntutan untuk mampu melakukan interaksi sosial atau menjalin hubungan yang baik dengan orang lain. Interaksi sosial ini merupakan salah satu faktor yang turut mempengaruhi perkembangan siswa, namun di sisi lain interaksi sosial di sekolah ini juga menjadi salah satu sumber stres bagi siswa seperti, menimbulkan ketegangan dalam diri siswa yaitu; ketidakmampuan dalam menjalin hubungan positif dengan guru dan teman sebaya, keharusan menghadapi persaingan dengan teman, adanya perlakuan guru yang tidak adil, adanya sikap kurangnya perhatian dan dukungan dari guru dan sikap dijauhi bahkan dikucilkan teman.

Komisi Perlindungan Anak Indonesia (KPAI) sudah menerima lebih dari 51 pengaduan dari berbagai daerah mengenai anak-anak yang menjadi tertekan dan kelelahan karena beban tugas yang diberikan selama belajar daring, dimana jangka waktu untuk mengerjakannya juga tidak terlalu banyak dan diberbagai daerah tidak memiliki akses internet yang bagus serta beberapa dari mereka juga tidak memiliki kuota yang cukup untuk mendengarkan materi dari guru. Jika anak-anak terbebani maka hal itu bisa menimbulkan masalah kesehatan fisik dan juga mental, dimana hal itu juga akan mempengaruhi imusnitas tubuhnya (Tim KPAI, 2020).

Seperti kasus yang terjadi di salah satu desa di provinsi Sulawesi Selatan yaitu ditemukannya mayat pelajar kelas 2 SMA terbujur kaku di bawah tempat tidurnya pada Sabtu, 17 Oktober 2020 pukul 08.30 WITA. Mayat tersebut berinisial $\mathrm{Ml}$ yang berusia 16 tahun. Menurut keterangan aparat kepolisian

Deswita Anggrini, Program Studi Psikologi Fakultas Ilmu Pendidikan Universitas Negeri Padang. Email: deswita,anggrini@gmail.com 
Jurnal Psikologi Malahayati, Volume 3, No.1, Maret 2021: 39-46

\section{FAKTOR-FAKTOR PEMICU STRES PADA SISWA SMA SELAMA PEMBELAJARAN DARING}

setempat penyebab MI melakukan bunuh diri ialah karena $\mathrm{Ml}$ mengalami stress akibat banyaknya tugas daring dari sekolahnya, MI sering mengeluh kepada teman-temannya bahwa ia kesulitan untuk mengakses internet sehingga menyebabkan tugas-tugas daringnya menumpuk. Hal ini diketahui dari telepon genggam milik $\mathrm{Ml}$, dimana di dalam telepon genggam tersebut terdapat video berdurasi 32 detik yang menampilkan ketika MI menenggak racun rumput (Aco, 2020).

Hampir semua sekolah diseluruh daerah Indonesia pada saat ini melakukan belajar daring sepenuhnya, termasuk di Kabupaten Tanah Datar, Sumatera Barat. Mengatur waktu bagi peserta didik sangat penting agar teteap sehat mental selama pandemi ini. Namun berdasarkan observasi yang peneliti lakukan banyak peserta didik yang mengeluh bahwa mereka pusing selama belajar daring, banyak tuntutan yang harus mereka kerjakan, mereka mengaku kesulitan untuk membagi waktu untuk belajar. Siswa juga mengeluh karena jaringan internet yang kurang bagus di beberapa daerah di Tanah Datar. Selain itu rata-rata masyarakat di Kabupaten Tanah bekerja sebagai petani yang pergi pagi dan pulang sore harinya, sehingga ketika anakanaknya belajar di rumah tidak mendapatkan pengawasan dari orang tuanya dan sebagian dari guru di Kabupaten Tanah Datar juga kesulitan untuk menggunakan teknologi dan internet, sehingga mengakibatkan tidak efektifnya pembelajaran daring.

Berdasarkan fenomena-fenomena yang dipaparkan diatas peneliti tertarik untuk meneliti apa saja faktor-faktor pemicu stress pada siswa-siswi Sekolah Menengah Atas (SMA) selama belajar daring di Kabupaten Tanah Datar. Penelitian ini bertujuan untuk menggali permasalahan-permasalahan yang dialami oleh siswa selama pembelajaran daring hingga menimbulkan stres.

\section{METODE}

Penelitian ini menggunakan metode kualitatif dengan melibatkan 50 informan siswa Laki-Laki $(n=7)$ dan perempuan $(n=43)$ yang bersekolah di SMA $(n=40)$, dan MA $(n=10)$ di Kabupaten Tanah Datar. Pengambilan data dilakukan menggunakan survei daring dimana informan diminta untuk mengisi beberapa pertanyaan terbuka dan tertutup terkait pengalamannya melakukan pembelajaran daring. Secara spesifik pertanyaan utama yang harus dijawab oleh subjek ialah mengenai pemicu stres ketika pembelajaran daring, kendala ketika belajar daring dan upaya yang dilakukan untuk mengurangi stres ketika belajar daring. Penyebaran datanya dilakukan dengan bantuan media sosial yaitu dengan pengisian kuisiner dari Google From.

Data yang diperoleh dari informan kemudian dianalisis dan dikelompokkan berdasarkan tema-tema yang lebih luas. Adapun

Deswita Anggrini, Program Studi Psikologi Fakultas Ilmu Pendidikan Universitas Negeri Padang. Email: deswita,anggrini@gmail.com 
Jurnal Psikologi Malahayati, Volume 3, No.1, Maret 2021: 39-46

\section{FAKTOR-FAKTOR PEMICU STRES PADA SISWA SMA SELAMA PEMBELAJARAN DARING}

tahapan dalam menganalisa jawaban dari partisipan yaitu dengan mencoding jawaban dari partisipan terlebih dahulu lalu menganalisa jawaban tersebut. Hasil analisa inilah nantinya akan didapatkan beberapa kategori faktor apa saja yang menjadi pemicu stres pada siswasiswi sekolah menengah atas (SMA) selama melakukan pembelajaran daring.

\section{HASIL PENELITIAN}

Pembelajaran daring banyak dilakukan dengan menggunakan berbagai macam media seperti, telepon genggam, laptop, buku paket, buku modul, dan buku pelajaran lainnya.
Berdasarkan hasil analisis data dari 50 responden didapatkan bahwa sebanyak 25 responden menggunakan telepon genggam, 18 responden menggunakan telepon genggam dan buku, dan 7 orang responden menggunakan telepon genggam, buku, dan laptop untuk belajar daring.

Tabel 1 menunjukkan kendala apa saja yang dialami oleh 50 orang responden selama belajar, tabel 2 menunjukkan hal apa saja yang dirasakan selama belajar daring dan tabel 3 menunjukkan upaya 50 orang responden dalam mengatasi kendala yang muncul. Hasil analisis disajikan dalam tabel berikut :

Tabel 1

Kendala Selama Belajar Daring

\begin{tabular}{ll}
\hline Kendala Selama Belajar Daring & $\mathrm{N}$ \\
\hline Kesulitan dalam mengerjakan tugas & 33 \\
\hline Jaringan Internet yang tidak stabil dan kuota internet yang tidak cukup & 22 \\
\hline Kurangnya waktu untuk mengerjakan tugas & 22 \\
\hline Tidak mengerti materi pembelajaran & 12 \\
\hline
\end{tabular}

Berdasarkan tabel 1 ditemukan bahwa sebanyak 33 orang responden mengalami kesulitan dalam mengerjakan tugas yang dikarenakan banyaknya tugas yang diberikan oleh guru dan kurangnya pemahaman terhadap materi yang disampaikan. Selain itu koneksi internet menjadi masalah yang cukup berpengaruh dalam proses pembelajaran daring. Siswa merasa cemas dan khawatir jika jaringan internet tidak stabil yang akan menyebabkan terjadinya berbagai kendala

Deswita Anggrini, Program Studi Psikologi Fakultas Ilmu Pendidikan Universitas Negeri Padang. Email: deswita,anggrini@gmail.com teknis dan ketika tidak mampu membeli kuota internet. Kendala teknis yang dimaksud antara lain seperti tugas yang tidak terkirim, terlambat mengikuti kelas, hingga kesulitan mendengarkan penjelasan guru dengan baik. Perbedaan akses teknologi yang dimiliki setiap siswa membuat beberapa siswa kesulitan dalam mengikuti pembelajaran dengan lancar (Morgan, 2020). Kesulitan tersebut semakin terasa bagi siswa yang tinggal di daerah-daerah yang tidak 
Jurnal Psikologi Malahayati, Volume 3, No.1, Maret 2021: 39-46

\section{FAKTOR-FAKTOR PEMICU STRES PADA SISWA SMA SELAMA PEMBELAJARAN DARING}

memiliki jaringan internet memadai (Hastini et

al., 2020).

Tabel 2

Hal Yang Dirasakan Selama Belajar Daring

\begin{tabular}{ll}
\hline Hal Yang Dirasakan Selama Belajar Daring & N \\
\hline Cemas Ketika Tidak Dapat Mengerjakan Tugas Tepat Waktu & 22 \\
\hline Kecewa Ketika Nilai Yang Diperoleh Menurun & 18 \\
\hline
\end{tabular}

Dalam tabel 2 menunjukkan bahwa hal terbebani dengan adanya tekanan-tekanan yang membuat siswa merasa tertekan dan untuk menunjukkan prestasi dan keunggulan memunculkan rasa cemas dan takut apabila tidak dapat mengumpulkan tugas tepat waktu dan siswa merasa kecewa ketika mengalami dalam persaingan akademik yang semakin meningkat atau bisa dikatakan siswa tersebut mengalami stres akademik (Agista, 2011).

penurunan nilai. Hal ini akan membuat siswa

Tabel 3

Upaya Mengatasi Kendala Selama Belajar Daring

Upaya Mengatasi Kendala Selama Belajar Daring N

Mencari Solusi Dari Masalah Yang Ada 26

Meminta Bantuan / Bertanya Kepada Teman 41

Meminta Bantuan / Bertanya Kepada guru

46

Adapun upaya (tabel 3) yang dilakukan siswa dalam mengatasi kendala yang ada ialah dengan meminta bantuan / bertanya kembali kepada guru $(n=46)$, meminta bantuan / bertanya kepada teman $(n=41)$ dan mencari solusi dari setiap masalah yang muncul $(n=26)$. Selama belajar daring siswa masih intens (sering) melakukan komunikasi dengan temantemannya $(n=41)$.

\section{DISKUSI}

Kesulitan Dalam Mengerjakan Tugas, kurangnya waktu untuk mengerjakan tugas dan tidak mengerti materi pembelajaran merupakan hal-hal yang berkaitan dengan permasalahan di dalam kegiatan akademik. Hasil ini sesuai dengan teori yang menyatakan bahwa penyebab stres mahasiswa yaitu stres akibat akademik, akibat masalah interpersonal, akibat kegiatan pembelajaran, akibat hubungan sosial, akibat dorongan dan keinginan serta akibat aktivitas kelompok (Fink, 2009; Yusoff \& Rahim, 2010). Hasil ini sejalan dengan penelitian Cao, Fang, Hou, Han, Xu, Dong, dan Zheng (2020) yang menunjukkan bahwa keterlambatan kegiatan akademik berhubungan positif dengan

Deswita Anggrini, Program Studi Psikologi Fakultas Ilmu Pendidikan Universitas Negeri Padang. Email: deswita,anggrini@gmail.com 
Jurnal Psikologi Malahayati, Volume 3, No.1, Maret 2021: 39-46

\section{FAKTOR-FAKTOR PEMICU STRES PADA SISWA SMA SELAMA PEMBELAJARAN DARING}

gejala kecemasan mahasiswa selama pandemi

Covid-19. Namun dalam keadaan tidak pandemic Covid-19, tugas-tugas kuliah tidak mempunyai pengaruh yang signifikan terhadap tingkat stres mahasiswa (Hidayatulloh \& Aminoto, 2018).

Jaringan internet yang tidak stabil dan kuota internet yang tidak cukup merupakan salah satu faktor pemicu stres akademik. Hal ini sejalan dengan penelitian yang dilakukan oleh Morgan (2020) yang menyatakan bahwa koneksi internet menjadi masalah yang cukup berpengaruh dalam proses pembelajaran daring. Siswa merasa cemas dan khawatir jika jaringan internet tidak stabil dan ketika tidak mampu membeli kuota. Perbedaan akses teknologi yang dimiliki setiap siswa membuat beberapa siswa kesulitan dalam mengikuti pembelajaran dengan lancar. Kesulitan tersebut semakin terasa bagi siswa yang tinggal di daerah-daerah yang tidak memiliki jaringan internet memadai (Hastini, Fahmi, \& Lukito 2020).

\section{SIMPULAN DAN SARAN}

Stres akademik pada siswa Sekolah Menengah Atas selama pembelajaran daring yang dilakukan di masa pandemi covid-19 di Kabupaten Tanah Datar disebabkan karena kesulitan dalam mengerjakan tugas, tidak memahami materi pembelajaran, dan jaringan internet yang tidak stabil dan kuota internet yang tidak cukup. Adapun upaya yang dilakukan untuk mengatasi kendala yang ada ialah meminta bantuan / bertanya kepada guru dan teman, dan berusaha mencari solusi dari setiap masalah yang muncul.

Penelitian ini diharapkan mampu menjadi salah satu referensi dalam menerapkan sistem pembelajaran secara daring yang ramah siswa. Sehingga tercipta sistem pembelajaran daring yang lebih optimal dan dapat dijangkau oleh seluruh siswa dari berbagai kalangan. Penelitian berikutnya dapat dilakukan dengan wawancara guna memperdalam gambaran stress akademik yang dialami oleh siswa selama pembelajaran daring. Efektivitas atau keberhasilan dari strategi siswa dalam mengatasi stress akademik juga dapat dikaji lebih lanjut untuk mendapatkan gambaran yang lebih menyeluruh.

\section{DAFTAR PUSTAKA}

Aco, H. (2020). Siswa SMA Bunuh Diri Diduga Stres Akibat Tugas Belajar Online. Diunduh dari: https://www.tribunnews.com/regional/2 020/10/17/siswa-sma-bunuh-dirididuga-stres-akibat-tugas-belajaronline.

Agista, I. (2011). Penanganan Kasus Stres Dalam Menghadapi Aktivitas Kuliah Melalui Pendekatan Konseling Behavioristik Dengan Teknik Pengelolaan Diri Pada Mahasiswa Jurusan Seni Rupa FBS UNNES Tahun Ajaran 2010/2011 (Doctoral dissertation, Universitas Negeri Semarang).

Deswita Anggrini, Program Studi Psikologi Fakultas Ilmu Pendidikan Universitas Negeri Padang. Email: deswita,anggrini@gmail.com 
Jurnal Psikologi Malahayati, Volume 3, No.1, Maret 2021: 39-46

\section{FAKTOR-FAKTOR PEMICU STRES PADA SISWA SMA SELAMA PEMBELAJARAN DARING}

Asmara, C. G. (2020). Para siswa, simak surat terbaru Mendikbud Nadiem untuk kalian. CNBC Indonesia. Diunduh dari: https://www.cnbcindonesia.com/tech/20 20032512-4101-37-147405/para-siswasimak-surat-terbarumendikbud-nadiemuntuk-kalian.

Cao, W., Fang, Z., Hou, G., Han, M., Xu, X., Dong, J., \& Zheng, J. (2020). The psychological impact of the COVID-19 epidemic on college students in China. Psychiatry research, 287, 112934.

Desmita, D. (2010). Psikologi Perkembangan, cet ke-6. Bandung: PT Remaja Rosdakarya.

Fajar, T. (2020). Arti belajar di rumah di tengah wabah virus corona. Okezone News. Diunduh dari: https://www.news.okezone.com/read/2 020/03/25/65/2188872/arti-belajar-dirumah-di-tengah-wabahvirus-corona.

Fink, G. (2010). Stress: definition and history. Stress science: neuroendocrinology, 3(9).

Hastini, L. Y., Fahmi, R., \& Lukito, H. (2020). Apakah Pembelajaran Menggunakan Teknologi dapat Meningkatkan Literasi Manusia pada Generasi Z di Indonesia?. Jurnal Manajemen Informatika (JAMIKA), 10(1), 12-28.

Hidayatullah, F., \& Aminoto, C. (2018). Faktor eksternal tingkat stres mahasiswa keperawatan dalam adaptasi proses pembelajaran. Proceeding of The URECOL, 172-181.
Tim KPAI. (2020). Kebanjiran Pengaduan Dari Para Siswa yang Mengeluhkan Tugas di Luar Kewajaran. KPAl.go.id. diunduh dari https://www.kpai.go.id/berita/kpaikebanjiran-pengaduan-dari-para-siswayang-mengeluhkantugas-di-luarkewajaran pada Maret 2020.

Morgan, H. (2020). Best practices for implementing remote learning during a pandemic. The Clearing House: A Journal of Educational Strategies, Issues and Ideas, 93(3), 135-141.

Reva, K. (2014). Aplikasi Bimbingan Belajar jarak jauh (Distance learning) pelajaran matematika Berbasis WEB dengan Metode WBL. Pelita Informatika Budi Darma, 8(3).

Robbins, S. P. (2001). Perilaku Organisasi: Konsep, Kontroversi dan Aplikasi. Jilid I. Edisi Delapan. Edisi Bahasa Indonesia.

Rusdiana, E., \& Nugroho, A. (2020). Respon mahasiswa pada pembelajaran daring bagi mahasiswa mata kuliah pengantar hukum Indonesia UNESA. Integralistik, 31(1), 1-12.

Shukla, T., Dosaya, D., Nirban, V. S., \& Vavilala, M. P. (2020). Factors extraction of effective teaching-learning in online and conventional classrooms. International Journal of Information and Education Technology, 10(6), 422-427.

Yusoff, M. S. B., \& Rahim, A. F. A. (Eds.). (2010). The medical student stressor questionnaire (MSSQ) manual. Universiti Sains Malaysia.

Deswita Anggrini, Program Studi Psikologi Fakultas Ilmu Pendidikan Universitas Negeri Padang. Email: deswita,anggrini@gmail.com 